\title{
Costly litigation and optimal damages
}

\section{Citation}

A. Mitchell Polinsky \& Steven Shavell, Costly Litigation and Optimal Damages, 37 Int'l Rev. L \& Econ. 86 (2014).

\section{Published Version}

10.1016/j.irle.2013.05.002

\section{Permanent link}

http://nrs.harvard.edu/urn-3:HUL.InstRepos:30011105

\section{Terms of Use}

This article was downloaded from Harvard University's DASH repository, and is made available under the terms and conditions applicable to Open Access Policy Articles, as set forth at http:// nrs.harvard.edu/urn-3:HUL.InstRepos:dash.current.terms-of-use\#OAP

\section{Share Your Story}

The Harvard community has made this article openly available.

Please share how this access benefits you. Submit a story.

Accessibility 


\title{
HARVARD
}

JOHN M. OLIN CENTER FOR LAW, ECONOMICS, AND BUSINESS

\section{COSTLY LITIGATION AND OPTIMAL DAMAGES}

\author{
A. Mitchell Polinsky \\ Steven Shavell
}

Subsequently published in International Review of Law and Economics, Vol. 37 (March 2014)

Discussion Paper No. 739

$$
11 / 2012
$$

Harvard Law School

Cambridge, MA 02138

This paper can be downloaded without charge from:

The Harvard John M. Olin Discussion Paper Series:

http://www.law.harvard.edu/programs/olin_center/

The Social Science Research Network Electronic Paper Collection: http://ssrn.com/abstract=2173597 


\title{
Costly Litigation and Optimal Damages
}

\author{
A. Mitchell Polinsky and Steven Shavell ${ }^{*}$
}

\begin{abstract}
A basic principle of law is that damages paid by a liable party should equal the harm caused by that party. However, this principle is not correct when account is taken of litigation costs, because they too are part of the social costs associated with an injury. In this article we examine the influence of litigation costs on the optimal level of damages, assuming that litigation costs rise with the level of damages.
\end{abstract}

* Stanford Law School and Harvard Law School, respectively. Both authors are also Research Associates of the National Bureau of Economic Research. Polinsky's research was supported by the John M. Olin Program in Law and Economics at Stanford Law School, and Shavell’s by the John M. Olin Center for Law, Economics, and Business at Harvard Law School. 


\section{Costly Litigation and Optimal Damages}

(C) 2012. A. Mitchell Polinsky and Steven Shavell. All right reserved.

\section{Introduction}

The standard amount that a party who has been found liable for an injury must pay in damages is the harm caused. ${ }^{1}$ Several scholars have pointed out, however, that this basic principle of law is economically problematic because the social cost of a harmful event is not only the harm, but also the associated litigation costs. They have therefore argued that the injurer should bear the harm plus total litigation costs — which implies that the injurer should pay damages equal to the harm plus the victim's litigation costs, since the injurer already bears his own litigation costs. ${ }^{2}$

We explain here why this conclusion is incorrect when account is taken of the fact that litigation costs generally increase with the level of damages. Consequently, litigation costs can be saved by lowering damages. Due to this consideration, we demonstrate that optimal damages can lie anywhere between zero and the harm plus the victim's litigation costs. The proper level of damages in this range depends on the tradeoff between saving litigation costs and promoting incentives to prevent harm.

\footnotetext{
${ }^{1}$ See, for example, Restatement (Second) of Torts, § 901, comment a (1979) (“. . . the law of torts attempts primarily to put an injured person in a position as nearly as possible equivalent to his position prior to the tort.”); Restatement (Second) of Contracts, § 344, comment a (1981) (the court ordinarily awards damages that put the breached-against party "in as good a position as he would have been in had the contract been performed, that is, had there been no breach.”).

${ }^{2}$ See Polinsky and Rubinfeld (1988), Hylton (1990), and Shavell (1999).
} 
The issue we are studying is empirically significant because litigation costs are high — on average about two-thirds of harm — and are sensitive to the level of damages. ${ }^{3}$ For this reason, we believe that the optimal level of damages will often be less than the harm and, when the incentive effect of damages is low, could be zero.

We derive our results in section 2, illustrate them in section 3, and conclude in section 4.

\section{The Model}

We employ the standard model of accidents in which potential injurers take care to reduce the risk of accidents to strangers. ${ }^{4}$ We assume that if there is an accident the victim will decide whether to sue the injurer and, if he does, that both parties will bear litigation costs. These costs include a fixed component and a variable component that rises with the level of damages. ${ }^{5}$ We assume that liability is strict, that is, an injured party will be awarded damages if he brings a lawsuit, regardless of the injurer's level of care. ${ }^{6}$ The state selects the level of damages to minimize social costs, which equal the sum of the cost of care, the harm, and litigation expenses.

$$
\begin{aligned}
& \text { Let } \\
& \begin{aligned}
x & =\text { expenditure on care by an injurer; } x \geq 0 ; \\
q(x) & =\text { probability of an accident; } q^{\prime}(\cdot)<0 ; q^{\prime \prime}(\cdot)>0 ; \\
h & =\text { harm if an accident occurs; } h>0 ;
\end{aligned}
\end{aligned}
$$

${ }^{3}$ See paragraph (a) in section 4 below.

${ }^{4}$ The conclusions that we draw would be expected to carry over to harmful events other than accidents, and notably to breach of contract and violations of property rights.

${ }^{5}$ Our assumption that litigation costs rise with the level of damages not only has empirical support, as we noted, but also theoretical support. See Katz (1988). 
$d$ = damage payment by an injurer if an accident occurs and a suit is brought; $d \geq 0$;

$\gamma_{i}=$ fixed litigation costs of an injurer; $\gamma_{i} \geq 0$;

$\lambda_{i}(d)=$ variable litigation costs of an injurer; $\lambda_{i}(0)=0 ; 0<\lambda_{i}{ }^{\prime}(d)<1 ; \lambda_{i}{ }^{\prime \prime}(d) \leq 0$;

$\gamma_{v}=$ fixed litigation costs of a victim; $\gamma_{v} \geq 0$; and

$\lambda_{v}(d)=$ variable litigation costs of a victim; $\lambda_{v}(0)=0 ; 0<\lambda_{v}{ }^{\prime}(d)<1 ; \lambda_{v}{ }^{\prime \prime}(d) \leq 0$.

To obtain damages $d$ after an accident, a victim must sue the injurer, thereby incurring litigation costs of $\gamma_{v}+\lambda_{v}(d)$ and causing the injurer to bear litigation costs of $\gamma_{i}+\lambda_{i}(d)$. A victim will bring a suit if and only if damages equal or exceed his litigation costs, that is, when

$$
d \geq \gamma_{v}+\lambda_{v}(d)
$$

or when

$$
d \geq d_{0}
$$

where $d_{0}$ is the solution to ${ }^{7}$

$$
d=\gamma_{v}+\lambda_{v}(d)
$$

We denote the level of care taken by an injurer by $x(d)$. If $d<d_{0}$, then $x(d)=0$ because no suits will be brought. If $d \geq d_{0}$, then suits will be brought and the injurer's costs will be

$$
x+q(x)\left(d+\gamma_{i}+\lambda_{i}(d)\right) .
$$

The injurer will choose $x(d)$ so as to minimize (4). This level of precaution is unique since (4) is convex in $x$. The injurer will choose $x(d)=0$ if the derivative of (4) at 0 is non-negative:

$$
1+q^{\prime}(0)\left(d+\gamma_{i}+\lambda_{i}(d)\right) \geq 0
$$

otherwise $x(d)$ will be positive and determined by

\footnotetext{
${ }^{6}$ We comment on the negligence rule in section 4.
}

${ }^{7}$ Let $f(d)=d-\left(\gamma_{v}+\lambda_{v}(d)\right)$, and note that $f(0)=-\gamma_{v}, f^{\prime}(d)=1-\lambda_{v}{ }^{\prime}(d)>0$, and $f^{\prime \prime}(d) \geq 0$. Since $f(d)=0$ determines $d_{0}$ and $f^{\prime}(d)>0$, it follows that $d_{0}$ exists, must be unique, and has the claimed properties. Note that $\mathrm{d}_{0}$ will be positive if $\gamma_{v}>0$ and zero otherwise. 


$$
1+q^{\prime}(x)\left(d+\gamma_{i}+\lambda_{i}(d)\right)=0
$$

It straightforward to show that $x^{\prime}(d)$ is positive by differentiating (6) with respect to $d$.

If victims do not bring suits, social costs will be

$$
q(0) h .
$$

If victims do bring suits, social costs will be

$$
x(d)+q(x(d))\left(h+\gamma_{i}+\lambda_{i}(d)+\gamma_{v}+\lambda_{v}(d)\right) .
$$

Optimal damages, $d^{*}$, minimize social cost, which is (7) if $d<d_{0}$ and (8) if $d \geq d_{0}$. Note that if $0<d^{*}<d_{0}$, we can assume that $d^{*}=0$ because no suits will be brought. Therefore, $d^{*}$ is either 0 or at least $d_{0}$.

It will be informative to first examine a simplified version of the model in which there are no variable litigation costs.

Proposition 1. When litigation costs are comprised of fixed costs only, optimal damages are either zero or equal to the sum of the harm and the victim's fixed cost of litigation, $d^{*}=h+$ $\gamma_{v}$

Proof. We first show that $d^{*}$ cannot equal $d_{0}$, which in the present case is $\gamma_{v}$. Either $x\left(\gamma_{v}\right)$ $=0$ or $x\left(\gamma_{v}\right)>0$. If $x\left(\gamma_{v}\right)=0, d=\gamma_{v}$ cannot be optimal because one could achieve the same level of care by the injurer without incurring litigation costs, by choosing $d=0$. If $x\left(\gamma_{v}\right)>0$, it is also true that $d=\gamma_{v}$ cannot be optimal. In particular, (6) must hold, implying that

$$
1+q^{\prime}(x)\left(\gamma_{v}+\gamma_{i}\right)=0 .
$$

Additionally, the derivative of social costs (8) is

$$
x^{\prime}(d)\left[1+q^{\prime}(x(d))\left(h+\gamma_{i}+\gamma_{v}\right)\right] .
$$

Using (9), (10) reduces to $x^{\prime}(d) q^{\prime}(x(d)) h$, which is negative. Hence, $d=\gamma_{v}$ cannot be optimal. 
We now know that $d^{*}$ either is 0 or is greater than $d_{0}$, in which case it satisfies the firstorder condition

$$
x^{\prime}(d)\left[1+q^{\prime}(x(d))\left(h+\gamma_{i}+\gamma_{v}\right)\right]=0 .
$$

If $d^{*}>d_{0}$, it must be that $x\left(d^{*}\right)>0$, for if $x\left(d^{*}\right)=0$, then $d^{*}$ cannot be optimal by the argument given in the previous paragraph. Because $x\left(d^{*}\right)>0$, (6) applies and becomes $1+q^{\prime}(x)\left(d+\gamma_{i}\right)=$ 0. Thus, (11) can be written as

$$
q^{\prime}(x(d))\left(h-d+\gamma_{v}\right)=0
$$

implying that $d=h+\gamma_{v}$.

Either $d^{*}=0$ or $d^{*}=h+\gamma_{v}$ is possible. Clearly, $d^{*}=0$ is possible because, if the sum of $\gamma_{i}$ and $\gamma_{v}$ is sufficiently large, it will not be desirable to have lawsuits. Likewise, $d^{*}=h+\gamma_{v}$ is possible because, if the sum of $\gamma_{i}$ and $\gamma_{v}$ is sufficiently small, it will be desirable to have lawsuits.

Comments: The explanation of this result is two-fold. On one hand, if suits are socially worthwhile because their beneficial effects on the injurer's care decision more than justifies the resulting litigation costs, damages should equal the harm plus the victim's litigation costs. This will fully internalize the costs imposed on society whenever an accident occurs, given that a suit will result; there is no need for damages to reflect the injurer's litigation costs because the injurer will naturally bear these costs. On the other hand, if suits are not socially worthwhile because their beneficial effects on the injurer's care decision are offset by their associated litigation costs, optimal damages should be zero in order to forestall suits.

Essentially the same result — that optimal damages are either zero or the sum of the harm and the victim's fixed litigation cost — is shown in Polinsky and Rubinfeld (1988) in a different model of liability for accidents and in Shavell (1999) in a model similar to that considered here. 
A closely related result is obtained in Hylton (1990). Variable litigation costs are not considered in these articles.

We now state the main result in our model.

Proposition 2. When litigation costs are comprised of fixed and variable costs, optimal damages are either zero, equal to $d_{0}$, or exceed $d_{0}$ and satisfy (14) below. Hence, when optimal damages are positive, they are less than the sum of the harm and the victim's litigation costs, $d^{*}$ $<h+\gamma_{v}+\lambda_{v}\left(d^{*}\right)$.

Proof: We explained above that $d^{*}$ is either zero or at least $d_{0}$. Clearly, as in Proposition $1, d^{*}=0$ is possible because, if the sum of $\gamma_{i}$ and $\gamma_{v}$ is sufficiently large, lawsuits will be undesirable.

That $d^{*}$ can equal $d_{0}$ is demonstrated by an example below. The explanation in essence is that it could be socially desirable to induce suits in order to significantly lower the likelihood of accidents, but not to raise damages any more than is necessary to induce suits because doing so would increase litigation costs more than the additional benefits of risk reduction.

To see that $d^{*}$ can exceed $d_{0}$, observe that if there were no litigation costs, $d^{*}$ would equal harm $h$ (this follows from Proposition 1). Thus, if litigation costs are sufficiently low, $d^{*}$ will be close to $h$ and $d_{0}$ would be close to zero. Therefore, $d^{*}$ would exceed $d_{0}$.

To demonstrate that $d^{*}<h+\gamma_{v}+\lambda_{v}\left(d^{*}\right)$ when $d^{*}$ is positive, first suppose that $d^{*}=d_{0}$. Then $d^{*}=\gamma_{v}+\lambda_{v}\left(d^{*}\right)$ by (3), and hence $d^{*}<h+\gamma_{v}+\lambda_{v}\left(d^{*}\right)$. Second, suppose that $d^{*}>d_{0}$. Then $d^{*}$ must satisfy the first-order condition following from (8),

$$
\begin{gathered}
x^{\prime}(d)+x^{\prime}(d) q^{\prime}(x(d))\left(h+\gamma_{i}+\lambda_{i}(d)+\gamma_{v}+\lambda_{v}(d)\right) \\
+q(x(d))\left(\lambda_{i}^{\prime}(d)+\lambda_{v}{ }^{\prime}(d)\right)=0 .
\end{gathered}
$$


Observe that $x\left(d^{*}\right)>0$, for otherwise the same level of care by the injurer could be obtained without incurring litigation costs by choosing $d=0$. Therefore, (6) holds at $d^{*}$, so that (13) becomes

$$
x^{\prime}(d) q^{\prime}(x(d))\left(-d+h+\gamma_{v}+\lambda_{v}(d)\right)+q(x(d))\left(\lambda_{i}^{\prime}(d)+\lambda_{v}{ }^{\prime}(d)\right)=0 .
$$

Because $q(x(d))\left(\lambda_{i}^{\prime}(d)+\lambda_{v}{ }^{\prime}(d)\right)$ is positive, $x^{\prime}(d) q^{\prime}(x(d))\left(-d+h+\gamma_{v}+\lambda_{v}(d)\right)$ must be negative, which implies that $d^{*}<h+\gamma_{v}+\lambda_{v}\left(d^{*}\right)$.

Comments: The explanation of the result that optimal damages must be less than $h+\gamma_{v}+$ $\lambda_{v}\left(d^{*}\right)$ is as follows. If damages were equal to $h+\gamma_{v}+\lambda_{v}\left(d^{*}\right)$, then they would fully internalize the costs imposed on society whenever an accident occurs, given that a suit will result. It is desirable to reduce damages from this benchmark because doing so has no first-order effect on socially desirable internalization of social costs but does have a first-order beneficial effect on litigation costs, for they fall as damages are reduced.

\section{An Example}

To illustrate our results, let the probability of an accident be

$$
q(x)=.01+.09 e^{-.01 x} .
$$

Thus, if nothing is spent on care, the probability of an accident is .10, and expenditures on care cause this probability to decline asymptotically to .01. For instance, if $\$ 10$ is spent on care, the probability of an accident is .09; if $\$ 100$ is spent, the probability is .04; and if $\$ 200$ is spent, it is .02. Also, let the fixed litigation costs be $\gamma_{i}=\gamma_{v}=\$ 2,500$ and the variable litigation costs be

$$
\lambda_{i}(d)=\lambda_{i} d,
$$


where $0<\lambda_{i}<1$, and

$$
\lambda_{v}(d)=\lambda_{v} d
$$

where $0<\lambda_{v}<1$. Hence, from (3), the threshold value of $d$ below which victims will not sue is $d_{0}=\gamma_{v} /\left(1-\lambda_{v}\right)$. The level of harm $h$ and assumptions about the variable litigation cost parameters $\lambda_{i}$ and $\lambda_{v}$ will be discussed below.

First suppose that there are no variable litigation costs, $\lambda_{i}=\lambda_{v}=0$. Then optimal damages $d^{*}$ are zero for harm $h$ up to and including $\$ 3,989$, and equal to the harm plus the victim's fixed cost of litigation thereafter. Thus, for example, if $h=\$ 10,000, d^{*}=\$ 12,500$. This illustrates Proposition 1.

Now suppose that there are also variable litigation costs, with $\lambda_{i}=\lambda_{v}=.3 .^{8}$ Then $d^{*}=0$ if $h$ is at or below $\$ 4,704 ; d^{*}=d_{0}=\$ 3,572$ for $h$ between $\$ 4,705$ and $\$ 5,653$; and $d^{*}$ exceeds $\$ 3,572$ and rises with $h$ for $h$ greater than $\$ 5,653$. For example, if $h=\$ 10,000, d^{*}=\$ 5,459$; and if $h=\$ 25,000, d^{*}=\$ 10,702$. Obviously, since optimal damages are less than harm, they are less than the sum of the harm and the victim's litigation costs. ${ }^{9}$ These results illustrate Proposition 2.

Note that optimal damages are lower than the harm because of the sensitivity of variable litigation costs to the level of damages. Given $\lambda_{i}=\lambda_{v}=.3$, variable litigation costs decline by 60 cents for every dollar reduction in damages. If $\lambda_{i}$ and $\lambda_{v}$ were lower than .3 , the motive to lower damages in order to reduce litigation costs would not be as great and, consequently, optimal damages would tend to be higher. Consider the case in which $h=\$ 10,000, \lambda_{i}=\lambda_{v}=.3$, and $d^{*}=$ $\$ 5,459$. If instead $\lambda_{i}=\lambda_{v}=.2, d^{*}=\$ 6,663$; and if $\lambda_{i}=\lambda_{v}=.1, d^{*}=\$ 8,590$. For optimal

\footnotetext{
${ }^{8}$ A justification for choosing this value is provided in section 4; see especially note 11 .

${ }^{9}$ To illustrate, when $h=\$ 10,000$, the victim's litigation costs are $\$ 4,138(=\$ 2,500+(.3) \$ 5,459)$, so the sum of the harm and the victim’s litigation costs is $\$ 14,138$.
} 
damages to exceed the $\$ 10,000$ harm, $\lambda_{i}$ and $\lambda_{v}$ would have to be less than .0532 . If, for instance, $\lambda_{i}=\lambda_{v}=.02, d^{*}=\$ 11,392$

\section{Conclusion}

We conclude with several remarks about our analysis.

(a) Relevance of results. For every dollar transferred from an injurer to a victim through the tort liability system, approximately one dollar of litigation costs is incurred jointly by the parties. ${ }^{10}$ Under natural assumptions, this implies that lowering damages by one dollar would reduce litigation costs by approximately 67 cents. $^{11}$ Additionally, Lee and Willging (2010) show that lowering damages by one percent would lower litigation costs by half of a percent. ${ }^{12}$ These observations suggest that lowering damages would often significantly decrease litigation costs.

The countervailing argument to lowering damages is that injurers will have weaker incentives to reduce harm, but this point is not strong in some domains. Notably, incentives to reduce harm would not be affected very much by lower damages when firms face rigorous safety regulation or strong market discipline. Thus, in some important contexts optimal damages may well be less than harm.

(b) Settlements. That most cases settle out of court does not fundamentally alter our conclusions. First, cases that settle tend to involve costs because parties often gather evidence,

${ }^{10}$ See Polinsky and Shavell (2010, pp. 1469-70).

${ }^{11}$ Suppose all litigation costs are variable costs and proportional to damages, and that the victim's and the injurer's litigation costs are the same. Specifically, let each party bear litigation costs equal $\lambda d$. Given the observation that the parties' joint litigation costs equal the amount of damages retained by the victim, the following condition would hold: $2 \lambda d=(1-\lambda) d$. Solving for $\lambda$ yields $\lambda=1 / 3$, so $2 \lambda=2 / 3$. This conclusion would not be affected very much if fixed costs are positive but only a small fraction of total litigation costs. 
negotiate with each other, and make certain filings or appearances in court before reaching a settlement. Second, settlement costs would be expected to rise with the level of damages that would be awarded at trial for the same reasons that trial costs would rise. Thus, the motive to lower damages in order to reduce legal costs would remain if settlements were taken into account.

(c) Negligence rule. Although optimal damages depend on litigation costs under strict liability, they do not depend on litigation costs under the negligence rule in the standard model of accidents and liability. The reason is that litigation does not actually occur under the negligence rule, for injurers are led to be non-negligent. ${ }^{13}$ Hence, there is no motive to alter damages from harm on account of litigation costs. However, in more realistic models of the negligence rule, litigation would occur and therefore the general points that we have developed here would be relevant.

(d) Alternative ways to control litigation costs. Rather than constraining litigation costs by lowering damages, such costs could be controlled directly by regulating how much parties spend on litigation or by taxing litigation expenditures. However, these alternatives might not be easy to implement because it will often be difficult to identify the resources that parties invest in litigation. Notably, the time devoted to a case by the parties (as opposed to their attorneys) generally will not be observable. Additionally, a lawyer representing a party on a contingency fee basis might not keep a record of how much time he expends on the matter. An advantage of

\footnotetext{
${ }^{12}$ Because Lee and Willging assume that the elasticity of litigation costs with respect to damages is constant, the effect on litigation costs of lowering damages by one dollar varies with the level of damages. For other evidence that litigation costs rise with the level of damages, see Hersch and Viscusi (2007).

${ }^{13}$ In the conventional analysis of the negligence rule, damages equal harm, courts do not make errors in applying the negligence standard, injurers perfectly control their conduct, and victims accurately observe injurers' levels of care. Injurers then choose to be non-negligent and victims do not sue because they know that they would lose.
} 
controlling litigation costs by lowering damages is that this method will desirably dampen litigation expenditures even when the parties' investments in litigation cannot be regulated or taxed. A further advantage of using damages rather than regulation to control litigation costs is that the former approach provides flexibility to the parties to allocate their litigation expenditures (for example, between lawyers and experts) in the most efficient way given the circumstances of their case, whereas regulation would impose restrictions on them that are not tailored to their case. 


\section{References}

Hersch, Joni, and W. Kip Viscusi, “Tort Liability Litigation Costs for Commercial Claims,” American Law and Economics Review, Vol. 9 (2007), pp. 330-69.

Hylton, Keith, “The Influence of Litigation Costs on Deterrence under Strict Liability and under Negligence,” International Review of Law and Economics, Vol. 10 (1990), pp. 161-71.

Katz, Avery, “Judicial Decisionmaking and Litigation Expenditure,” International Review of Law and Economics, Vol. 8 (1988), pp. 127-43.

Lee III, Emery G., and Thomas E. Willging, “Litigation Costs in Civil Cases: Multivariate Analysis,” Report to the Judicial Advisory Committee on Civil Rules, Federal Judicial Center, March 2010 (available at http://www.fjc.gov/public/pdf.nsf/lookup/costciv1.pdf/ \$file/costciv1.pdf).

Polinsky, A. Mitchell, and Daniel L. Rubinfeld, “The Welfare Implications of Costly Litigation for the Level of Liability,” Journal of Legal Studies, Vol. 17 (1988), pp. 151-64.

Polinsky, A. Mitchell, and Steven Shavell, “The Uneasy Case for Product Liability,” Harvard Law Review, Vol. 123 (2010), pp. 1437-92.

Shavell, Steven, “The Fundamental Divergence Between the Private and the Social Motive to Use the Legal System,” Journal of Legal Studies, Vol. 26 (1997), pp. 575-612.

Shavell, Steven, “The Level of Litigation: Private Versus Social Optimality of Suit and of Settlement,” International Review of Law and Economics, Vol. 8 (1999), pp. 127-43. 